\title{
Technique of Mathematical Synthesis of Waveguide Iris Polarizers
}

\author{
A.V. Bulashenko ${ }^{1, *}$, S.I. Piltyay ${ }^{1, \dagger}$, I.I. Dikhtyaruk ${ }^{1, \ddagger}$, O.V. Bulashenko ${ }^{2, \S}$ \\ ${ }^{1}$ National Technical University of Ukraine "Igor Sikorsky Kyiv Polytechnic Institute", 37, Peremohy Ave., \\ 03056 Kyiv, Ukraine \\ ${ }^{2}$ Ivan Kozhedub Shostka Professional College of Sumy State University, 1, Institutskaya St., \\ 41100 Shostka, Ukraine
}

(Received 16 April 2021; revised manuscript received 20 October 2021; published online 25 October 2021)

\begin{abstract}
In this article, we have developed a new mathematical technique for synthesis of waveguide iris polarizers with optimal phase and matching characteristics. The technique applies theoretical single-mode expressions of the differential phase shift between the waves with orthogonal linear polarizations and of the voltage standing wave ratio to optimize the geometrical dimensions of the polarizer's structure. These expressions were combined into a set of mathematical conditions to obtain the required values of characteristics. The proposed technique was implemented to synthesize a waveguide polarizer with two thin conducting irises. Such irises are equivalent to inductive or capacitive loads in a waveguide transmission line, depending on the polarization type of the fundamental electromagnetic mode. The mathematical model of the waveguide iris polarizer was developed based on the equivalent wave matrices. As a result, the main electromagnetic characteristics were determined through the elements of the polarizer's scattering matrix. Suggested analytical synthesis technique allows to find all optimal geometrical dimensions of the iris polarizer including the transversal sizes of a square waveguide, the heights of the irises and the distances between them. Variation of these dimensions allows to obtain the required electromagnetic characteristics of microwave waveguide devices, namely the optimal matching and cross polarization level in the operating frequency band. The differential phase shift of $90^{\circ} \pm 0.5^{\circ}$ was obtained for the square waveguide iris polarizer optimized for the operating satellite frequency band 8.0-8.5 GHz. The voltage standing wave ratio does not exceed 2 for the fundamental modes of vertical and horizontal linear polarizations. The crosspolarization level of the iris polarizer is less than $-34 \mathrm{~dB}$. The axial radio does not exceed $0.4 \mathrm{~dB}$. Therefore, the presented mathematical method for single-mode synthesis of waveguide polarizers with diaphragms can be used to initially optimize them before the application of specialized programs for simulation of microwave devices. In addition, the suggested technique of mathematical synthesis can be widely used for the development of new microwave polarizers, phase shifters and filters based on irises and posts in waveguides.
\end{abstract}

Keywords: Electromagnetic simulation, Microwave engineering, Waveguide components, Synthesis of microwave devices, Scattering matrix, Transmission matrix, Polarizer, Waveguide polarizer, Iris polarizer, Circular polarization.

DOI: 10.21272/jnep.13(5).05024

PACS numbers: 84.40.Az, 84.40.Ua

\section{INTRODUCTION}

The impetuous progress of modern wireless telecommunication systems in the millimeter wavelength range leads to the development of new information processing methods in communication channels. Mentioned radio engineering and information appliances include 5G wireless communication systems, satellite information systems, and various radars. The requirements for the increase in information capacity in wireless channels led to the evolution of new devices for the processing of signal's polarization. The transformation of polarization type in microwave antenna systems from circular to linear or vice versa is performed in waveguide polarizers.

One of the first publications on the creation of devices with circular polarization [1] proposed a design that provided a differential phase shift of $90^{\circ}$ at the output port. This was achieved by using thin conducting irises placed in a square waveguide. Such irises create the necessary phase difference, because for one mode they act as inductive conductivities, and for another mode they act as capacitive conductivities. As a result, the first X-band polarizers were developed in [1].

The first designs of waveguide polarizers with metal septums were published in [2]. The proposed septum polarizer based on a square waveguide generated signals with left and right circular polarizations in a relative frequency band of $20 \%$.

The analysis of polarizers using the method of field expansion into eigenmodes was proposed in [3]. This method was used to analyze a polarizer based on a corrugated square waveguide. The polarizer was developed for the satellite bands $11.9-12.3 \mathrm{GHz}$ and 17.5 $17.9 \mathrm{GHz}$. It provided a differential phase shift of $90^{\circ} \pm$ $1^{\circ}$ with a maximum standing wave ratio of 1.02 .

In [4], the authors proposed a new method for creating wideband polarizers with irises in square and circular waveguides. The method made it possible to find the best matching condition for both polarizations by analyzing the frequency responses of the reflection coefficients. The results of the development of new

\footnotetext{
*a.bulashenko@kpi.ua

† crosspolar@ukr.net

‡ kotovan99@i.ua

$\S$ bulashenko2020@gmail.com
} 
irises profiles for waveguide polarizers were presented in [5]. The profiles were selected in such a way, that ensured the minimum deviation of the differential phase shift from $90^{\circ}$. In [6], a new method was proposed for the development of a broadband waveguide polarizer with irises for a C-band antenna feed system. In [7], the authors proposed a new method for the synthesis of microwave filters. The method is based on the representation of a filter by the scattering matrix. In [8-11], a new concept of designing waveguide polarizers with irises in the form of slot structures was proposed. Designs of suggested polarizers based on circular and rectangular waveguides were presented.

The structure of a tunable polarizer with circular and linear polarizations was proposed in [12]. This design is used in satellite communication systems. A number of works $[13,14]$ were devoted to the development of polarizers based on a square waveguide with a different number of irises for the Ku-band.

In [15], the researchers presented an accurate equivalent microwave circuit for a wideband iris located in a waveguide. An orthomode transducer for the separation of orthogonally polarized electromagnetic waves was proposed in [16]. This design provides good matching, small sizes and weight reduction.

Several techniques for the synthesis of passive microwave filters were recently presented in [17, 18]. The suggested techniques allow to create fully capacitive or inductive filters. In [19], a technique for the parametric synthesis of waveguide polarizers with irises for the operating C-band 3.4-4.2 GHz is proposed.

Nevertheless, a significant number of modern studies on waveguide polarizers [20-23] are devoted mainly to their modeling using commercial software, and little attention is paid to the theoretical and mathematical methods of their development.

Consequently, despite the availability of large number of papers devoted to the simulation and optimization of waveguide polarizers and microwave filters, the methods of their synthesis were not covered. Therefore, in this research, we develop a new technique of mathematical synthesis of waveguide polarizers.

\section{WAVE MATRIX MODEL OF A POLARIZER BASED ON A SQUARE WAVEGUIDE WITH IRISES}

Theoretical analysis will be performed on the example of a polarizer based on a square waveguide with two irises. Fig. 1 shows the 3D model and internal dimensions of the synthesized polarizer. The size of the square waveguide walls is designated as $a$. The irises have the same height $h$. The thicknesses of all irises are infinitely small. The gaps between the irises are $l$.

Using the wave matrix technique, which was previously applied for waveguide iris polarizers analysis $[24,25]$, we develop a mathematical model suitable for rectangular and square waveguides loaded by irises. The obtained model is based on a microwave circuit with equivalent inductive and capacitive loads.

The normalized reactive conductivities of the inductive and capacitive irises are calculated by the following formulas [24]:
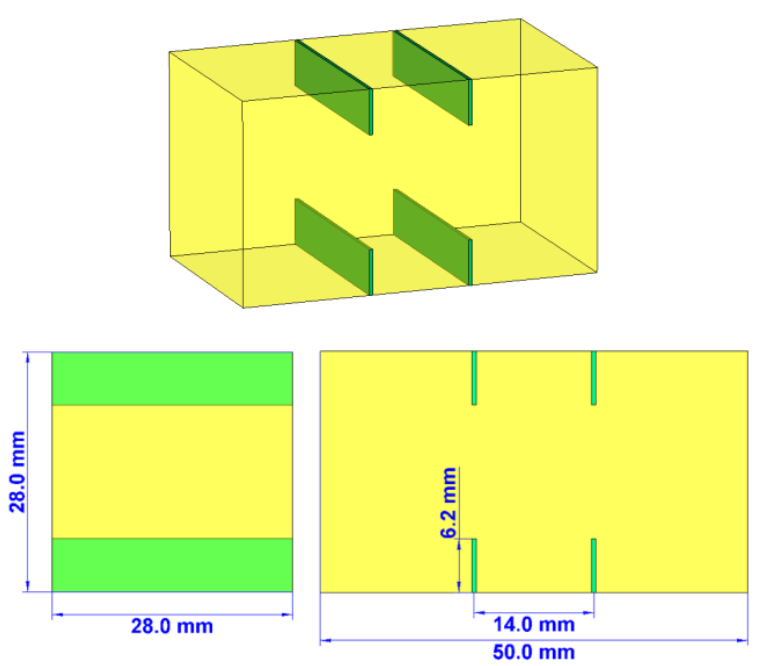

Fig. 1 - The structure of a waveguide polarizer with two irises

$$
\begin{gathered}
Y_{L} \cong-j \frac{\lambda_{g}}{a} \cdot\left[\operatorname{ctg}\left(\frac{\pi \cdot d}{2 a}\right)\right]^{2}, \\
Y_{C} \cong j \frac{4 a}{\lambda_{g}} \cdot \ln \left[\operatorname{cosec}\left(\frac{\pi \cdot d}{2 a}\right)\right],
\end{gathered}
$$

where $a$ is the transversal size of walls of the square waveguide, $d$ is the width of the iris window, $\lambda_{g}$ is the guide wavelength.

The guide wavelength is calculated as follows [19]:

$$
\lambda_{g}=\frac{\lambda}{\sqrt{1-\left(\frac{\lambda}{\lambda_{C}}\right)^{2}}},
$$

where $\lambda$ is the wavelength in free space, $\lambda_{C}$ is the cutoff wavelength for the fundamental $\mathrm{TE}_{10}$ mode in the waveguide.

To analyze the waveguide polarizer with two irises using the single-mode approximation, we will consider its equivalent circuit with two admittances connected in parallel into the transmission line (Fig. 2).

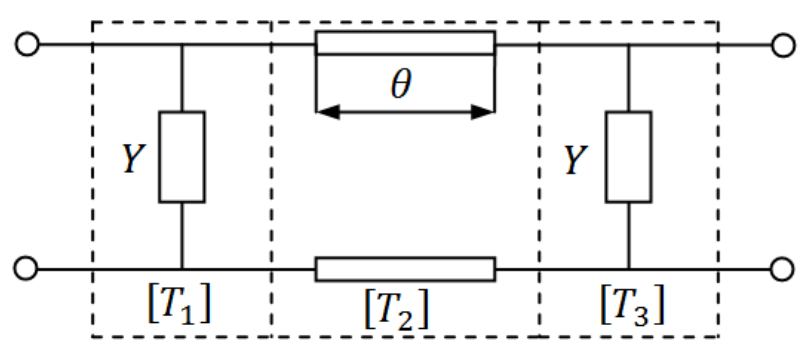

Fig. 2-Equivalent circuit of a waveguide polarizer with two irises

We will divide the equivalent circuit into simple four-terminal circuits to define the general scattering wave matrix. In Fig. 2 , there are two circuits in the form of a connected in parallel admittance and one circuit in the form of a section of a transmission line with electrical length $\theta$. It is calculated as follows: 


$$
\theta=\frac{2 \pi}{\beta}=\frac{2 \pi \cdot l}{\lambda_{g}},
$$

where $l$ is the length of the gap between irises in the waveguide.

Marked in the equivalent circuit (see Fig. 2) fourterminal circuits are described by the following wave transmission matrices:

$$
\left[T_{1}\right]=\left[T_{3}\right]=\left[\begin{array}{cc}
\frac{2+Y}{2} & \frac{Y}{2} \\
-\frac{Y_{1}}{2} & \frac{2-Y_{1}}{2}
\end{array}\right] ; \quad\left[T_{2}\right]=\left[\begin{array}{cc}
e^{j \theta} & 0 \\
0 & e^{-j \theta}
\end{array}\right]
$$

The wave transmission matrix of the complete equivalent circuit is the product of elementary transmission matrices:

$$
\left[T_{\Sigma}\right]=\left[T_{1}\right] \cdot\left[T_{2}\right] \cdot\left[T_{3}\right]=\left[\begin{array}{ll}
T_{\Sigma 11} & T_{\Sigma 12} \\
T_{\Sigma 21} & T_{\Sigma 22}
\end{array}\right],
$$

where

$$
\begin{gathered}
T_{\Sigma 11}=\frac{4 e^{j \theta}+4 Y e^{j \theta}-Y^{2} e^{-j \theta}+Y^{2} e^{j \theta}}{4}, \\
T_{\Sigma 12}=Y \cos (\theta)+\frac{j Y^{2} \sin (\theta)}{2}, \\
T_{\Sigma 21}=-Y \cos (\theta)-\frac{j Y^{2} \sin (\theta)}{2}, \\
T_{\Sigma 22}=-\frac{1}{4}(\cos (\theta-j \sin (\theta)) \cdot(4 Y-4+ \\
+2 j Y^{2} \sin (\theta)(\cos (\theta-j \sin (\theta)) .
\end{gathered}
$$

The relationship between the wave transmission and scattering matrices is as follows:

$$
\left[S_{\Sigma}\right]=\left[\begin{array}{ll}
S_{\Sigma 11} & S_{\Sigma 12} \\
S_{\Sigma 21} & S_{\Sigma 22}
\end{array}\right]=\frac{1}{T_{\Sigma 11}}\left[\begin{array}{cc}
T_{\Sigma 21} & |T| \\
1 & -T_{\Sigma 12}
\end{array}\right]
$$

where $|T|$ is the determinant of the general transmission matrix.

Hence, we obtain the reflection and transmission coefficients

$$
\begin{aligned}
& S_{\Sigma 11}=\frac{\mathrm{T}_{\Sigma 21}}{\mathrm{~T}_{\Sigma 11}}=\frac{2+2 e^{j 2 \theta}+Y e^{j 2 \theta}-Y^{2}}{4 e^{j 2 \theta}+4 Y e^{j 2 \theta}-Y^{2}+Y^{2} K e^{j 2 \theta}}, \\
& S_{\Sigma 21}=\frac{1}{\mathrm{~T}_{\Sigma 11}}=\frac{4 e^{j \theta}}{4 e^{j 2 \theta}+4 Y e^{j 2 \theta}-Y^{2}+Y^{2} e^{j 2 \theta}} .
\end{aligned}
$$

The electromagnetic characteristics of the polarizer, which must be calculated using the developed model, are the differential phase shift, axial ratio, voltage standing wave ratio (VSWR), and crosspolar discrimination (XPD).

The differential phase shift between the fundamental modes with perpendicular linear polarizations is determined as follows:

$$
\Delta \phi=\phi_{\mathrm{L}}-\phi_{\mathrm{C}}=\arg \left(S_{\Sigma 21 L}\right)-\arg \left(S_{\Sigma 21 C}\right) .
$$

VSWR is determined by the following formulas [19]:

$$
V S W R_{L}=\frac{1+\left|S_{\Sigma 11 L}\right|}{1-\left|S_{\Sigma 11 L}\right|}, \quad V S W R_{C}=\frac{1+\left|S_{\Sigma 11 C}\right|}{1-\left|S_{\Sigma 11 C}\right|}
$$

where $S_{\Sigma 11 \mathrm{~L}}, S_{\Sigma 11 \mathrm{C}}$ designate the reflection coefficients for the cases of inductive and capacitive irises, respectively.

The axial ratio at the output of the polarizer is calculated by the following formula [19]:

$$
r[\mathrm{~dB}]=10 \lg \frac{A^{2}+B^{2}+\sqrt{A^{4}+B^{4}+2 A^{2} B^{2} \cos (2 \Delta \phi)}}{A^{2}+B^{2}-\sqrt{A^{4}+B^{4}+2 A^{2} B^{2} \cos (2 \Delta \phi)}},
$$

where $A=\left|S_{\sum 21 \mathrm{~L}}\right|, \quad B=\left|S_{\sum 21 \mathrm{C}}\right|$, and $\Delta \varphi$ was defined in (10).

The XPD is expressed in $\mathrm{dB}$ and is calculated using the formula:

$$
\mathrm{XPD}[\mathrm{dB}]=20 \lg \left(\frac{r+1}{r-1}\right)
$$

where $r$ is the axial ratio in the linear scale.

Therefore, the performed analysis provides us with the formulas for calculating the required electromagnetic characteristics of the waveguide iris polarizer. The developed theory will be applied for the synthesis of an optimal iris polarizer in the next section.

\section{SYNTHESIS OF A WAVEGUIDE IRIS POLARIZER WITH OPTIMAL CHARACTERISTICS}

Developed in this section technique of mathematical synthesis allows us to obtain optimal electromagnetic characteristics of a waveguide iris polarizer. In the ideal case, it is necessary to provide the dependence of the differential phase shift on frequency in the form of a parabola or a line centered in the operating frequency band (Fig. 3). The parabola must cross the $90^{\circ}$ level at two frequencies. The line must cross the $90^{\circ}$ level at the central frequency of the operating band of the polarizer.

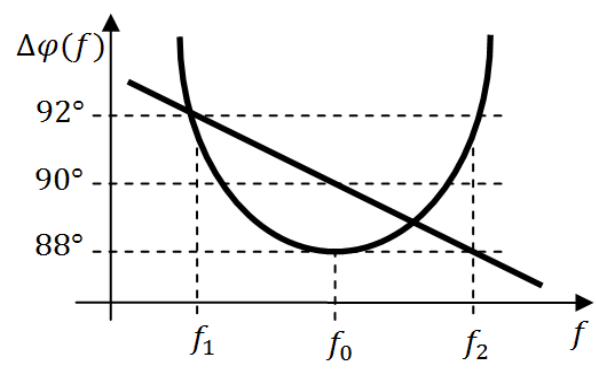

Fig. 3-Centered dependences of differential phase shift on frequency

Shown in Fig. 3 frequencies $f_{1}$ and $f_{2}$ are the boundary frequencies of the operating band, $f_{0}$ is the center frequency.

In order to synthesize the structure of a waveguide polarizer with the required frequency dependence of differential phase shift, we need to set the search conditions for the optimal dimensions of the polarizer model. 
In the general case, the differential phase shift is a function that depends on the frequency $f$, the size of the waveguide wall $a$, the height of irises $h$ and the distance between them $l$ :

$$
\Delta \phi(f)=\Delta \phi(f, a, h, l) .
$$

Let us set the mathematical conditions for the differential phase shift at the mentioned three frequencies as follows:

$$
\left\{\begin{array}{l}
\Delta \phi\left(f_{1}\right)=92^{\circ}, \\
\Delta \phi\left(f_{0}\right)=90^{\circ}, \\
\Delta \phi\left(f_{2}\right)=88^{\circ} .
\end{array}\right.
$$

As a result of the numerical solution of the written set of equations, we find the necessary values of the geometrical dimensions of the polarizer model. Optionally, in a given set of equations (15) we can change the values of the differential phase shift at the lowest and the highest frequencies of the operating band. Let us consider the evolution of phase and VSWR characteristics for the given values of the differential phase shift 91,93 , and $95^{\circ}$ at the lowest frequency and the corresponding values 89,87 , and $85^{\circ}$ at the highest frequencies. As a result, we obtain the following values of the differential phase shift 1,3 and $5^{\circ}$, respectively.

Fig. 4 and Fig. 5 show the dependences of the differential phase shift and VSWR on frequency for several synthesized polarizers, respectively. In Fig. 4, the curves 1,2 and 3 correspond to the differential phase variations $90^{\circ} \pm 1^{\circ}, 90^{\circ} \pm 3^{\circ}, 90^{\circ} \pm 5^{\circ}$.

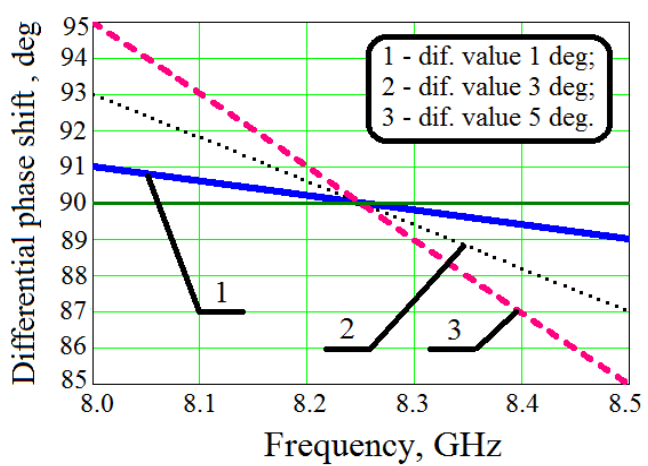

Fig. 4 - Dependences of differential phase shift on frequency

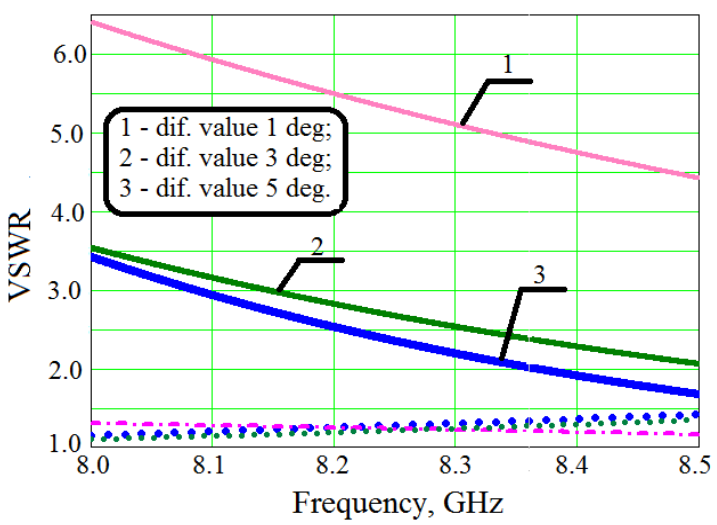

Fig. 5 - Dependences of VSWR on frequency
In Fig. 5, notations 1, 2 and 3 designate VSWR dependences for the horizontal linear polarization. Fig. 5 shows that the highest VSWR value is 6.4 for curve 1 . A decrease in the peak value of VSWR to 3.5 and 3.4 occurs for curves 2 and 3, respectively. Consequently, we can conclude that the increase in the values of the differential phase shift leads to a decrease in VSWR peak values. Besides, it was found that a further increase in the differential phase shift (up to the values more than $5^{\circ}$ ) does not result in a further decrease in the peak value of VSWR.

Consequently, an improvement of polarizer matching can be achieved only by changing the specified mathematical conditions, according to which the synthesis is carried out. Let us set new three conditions at the center frequency $f_{0}$ for differential phase shifts and VSWRs for both linear polarizations:

$$
\left\{\begin{array}{l}
\Delta \phi\left(a, d, l, f_{0}\right)=90^{\circ}, \\
V S W R_{\text {hor. pol }}\left(a, d, l, f_{0}\right)<2, \\
V S W R_{\text {vert. pol }}\left(a, d, l, f_{0}\right)<2 .
\end{array}\right.
$$

As a result of the numerical solution of the written system of conditions, we find the following optimal values of the sizes of the waveguide iris polarizer: $a=28 \mathrm{~mm}, l=14 \mathrm{~mm}, h=6.2 \mathrm{~mm}$. This combination of conditions will improve the matching of the synthesized polarizer by reducing the VSWR values.

Fig. 6 shows the dependence of the differential phase shift on frequency for the novel synthesized structure of the polarizer.

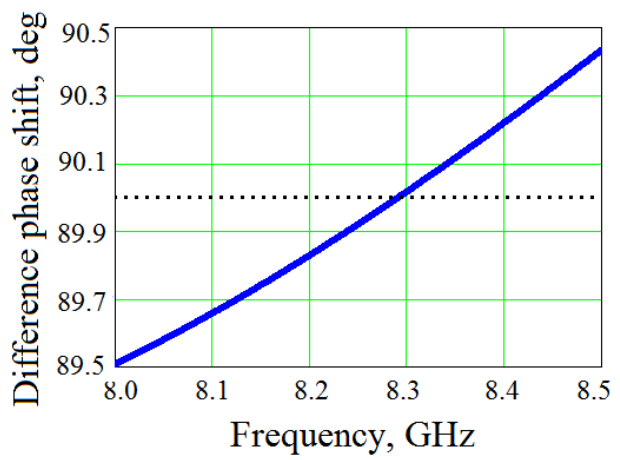

Fig. 6 - Dependence of differential phase shift on frequency

As we can observe in Fig. 6, the differential phase shift of the new synthesized design of the waveguide iris polarizer is $90^{\circ} \pm 0.5^{\circ}$ in the operating frequency band 8.0-8.5 GHz.

Fig. 7 demonstrates the dependences of VSWR vs. frequency for both perpendicular linear polarizations.

It is seen from Fig. 7 that the maximum value of VSWR in the operating frequency band for both polarizations is 1.97 .

Fig. 8 presents the dependence of the axial ratio of the synthesized polarizer on frequency in the operating band 8.0-8.5 GHz.

Fig. 8 shows that in the whole operating band 8.0$8.5 \mathrm{GHz}$ the axial ratio is less than $0.4 \mathrm{~dB}$. The minimum value of the axial ratio is $0 \mathrm{~dB}$. It is observed at a frequency of $8.31 \mathrm{GHz}$. 


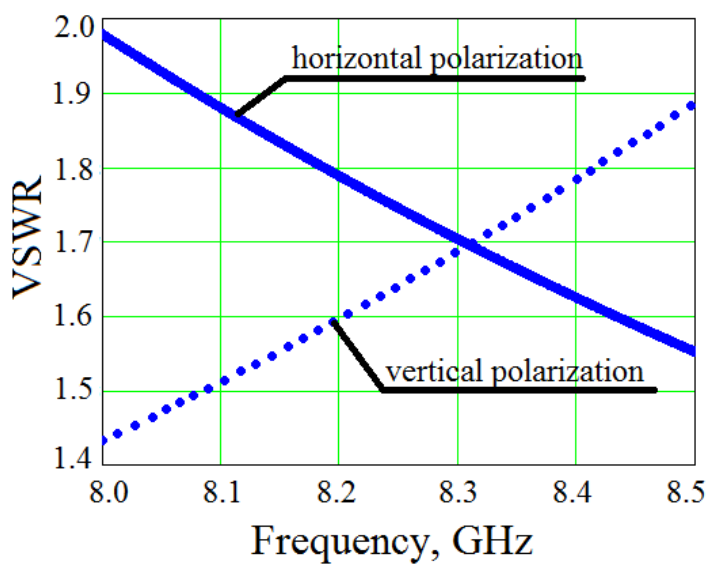

Fig. 7 - Dependences of VSWR on frequency for both polarizations

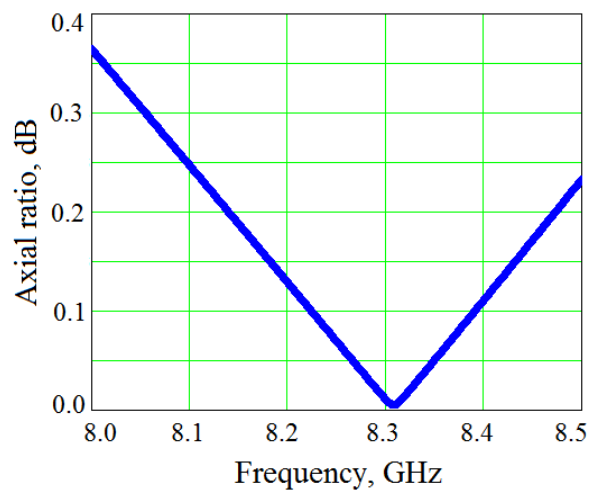

Fig. 8-Dependence of axial ratio of the iris polarizer on frequency

Fig. 9 presents the XPD of the synthesized polarizer versus frequency. In the operating frequency band, the crosspolarization level does not exceed the value of $-34 \mathrm{~dB}$. The worst isolation occurs at a frequency of $8.0 \mathrm{GHz}$. The minimum value of XPD is $-71 \mathrm{~dB}$. It occurs at a frequency of $8.31 \mathrm{GHz}$.

Therefore, in the operating frequency band 8.0$8.5 \mathrm{GHz}$ the new synthesized square waveguide polarizer with two irises provides VSWRs less than 2 for

\section{REFERENCES}

1. G. Birtin, B. Piovano, L. Accatino, M. Mongiardo, IEEE T. Microw. Theory 50 No 4, 1077 (2002).

2. N. Nikolic, A. Weily, I. Kekic, S.L. Smith, K.W. Smart, IEEE International Simposium on Antennas and Propagation \& USNC/URSI National Radio Science Meeting (APUSNCURSINRSM), art. No 8608909, 725 (Boston: IEEE: 2018).

3. C.A. Leal-Sevillano, J.R. Montejo-Garai, J.M. Rebollar, J.A. Ruiz-Cruz, 41st European Microwave Conference, art. No 6101919, 725 (Manchester: IEEE: 2011).

4. G. Virone, R. Tascone, M. Baralis, O.A. Peverini, A. Olivieri, R. Orta, IEEE T. Microw. Theory, 53 No 3, 888 (2004).

5. G. Virone, R. Tascone, O.A. Peverini, R. Orta, IEEE Microw. Wirel. Co. 17 No 3, 202 (2007).

6. G. Virone, R. Tascone, O.A. Peverini, G. Addamo, R. Orta, IEEE T. Microw. Theory. 18 No 8, 509 (2008).

7. R. Tascone, P. Savi, D. Trinchenko, R. Orta, IEEE T. Microw. Theory. 48 No 3, 423 (2000). both polarizations. The differential phase shift lies in the range of $90^{\circ} \pm 0.5^{\circ}$. The axial ratio is less than $0.4 \mathrm{~dB}$. The corresponding XPD is higher than $34 \mathrm{~dB}$.

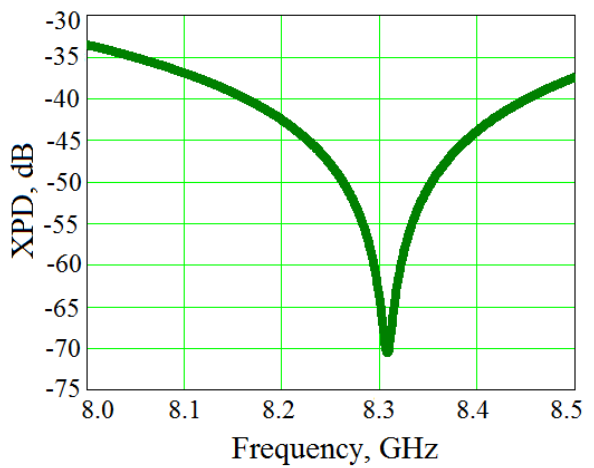

Fig. 9 - Dependence of XPD of the iris polarizer on frequency

\section{CONCLUSIONS}

A new technique for the synthesis of waveguide polarizers with irises has been developed in the article. The basic principles of the proposed technique are demonstrated by the synthesis of the new waveguide polarizer with two irises. The synthesis was carried out using conditions, which simultaneously combined conditions on the phase and matching characteristics. The characteristics were determined using the elements of the scattering matrix of the polarizer. In addition, the polarization characteristics were calculated to verify the performance.

The differential phase shift of the synthesized polarizer is $90^{\circ} \pm 0.5^{\circ}$. The crosspolar discrimination is higher than $34 \mathrm{~dB}$. The obtained results confirm the efficiency of the suggested technique of mathematical synthesis for the fast development of new waveguide polarizers with excellent polarization performance.

Therefore, a new technique of mathematical synthesis presented in the study can be recommended for the development and optimization of modern waveguide components for microwave radars, 5G wireless telecommunication appliances, satellite information systems and other applications.

8. A.O. Perov, A.A. Kirilenko, V.N. Derkach, IEEE Antenn. Wirel. Pr. 16, 117 (2015).

9. D.Yu. Kulik, L.P. Mospan, A.O. Perov, N.G. Kolmakova, Telecomm. Radio Eng. 75 No 10, 857 (2016).

10. D.Yu. Kulik, S.A. Steshenko, A.A. Kirilenko, Telecomm. Radio Eng. 76 No 10, 855 (2017).

11. A.A. Kirilenko, S.O. Steshenko, V.N. Derkach, Y.M. Ostryzhnyi, IEEE T. Microw. Theory. 67 No 2, 592 (2019).

12. F. Farzami, S. Khaledian, B. Smida, D. Erricolo, IEEE T. Antenn. Propag. Co. 66 No 1, 9 (2017).

13. S.I. Piltyay, A.V. Bulashenko, I.V. Demchenko, J. NanoElectron. Phys. 12 No 5, 05024 (2020).

14. S.I. Piltyay, O.Yu. Sushko, A.V. Bulashenko, I.V. Demchenko, Telecomm. Radio Eng. 79 No 19, 1673 (2020).

15. C.A. Leal-Sevillano, J.R. Montejo-Garai, J.A. Ruiz-Cruz, J.M. Rebollar, IEEE T. Microw. Theory. 64 No 3, 724 (2016).

16. J.A. Ruiz-Cruz, J.R. Montejo-Garai, C.A. Leal-Sevillano, J.M. Rebollar, IEEE T. Antenn. Propag. Co. 66 No 3, 1160 
(2018).

17. Y. Yang, Y. Zeng, M. Yu, Q.Wu, IEEE T. Microw. Theory. 69 No1, 639 (2021).

18. E. Guerrero, J. Verdu, P. Paco, IEEE Microw. Wirel. Co. 31 No1, 17 (2021).

19. S.I. Piltyay, A.V. Bulashenko, I.V. Demchenko, Telecomm. Radio Eng. 79 No 18, 1579 (2020).

20. K. Al-Amoodi, R. Mirzavand, M.M. Honari, J. Melzer, D.G. Elliott, P. Mousavi, IEEE Antenn. Wirel. Pr. 19, No 12, 2517 (2020).
21. N. Luo, X. Yu, G. Mishra, S.K. Sharma, IEEE Antenn. Wirel. Pr. 19, No 11, 1933 (2020).

22. B. Deutschmann, A.F. Jacob, IEEE T. Microw. Theory. 68 No2, 693 (2019).

23. E. Arnieri, F. Greco, L. Boccia, G. Amendola, IEEE T. Antenn. Propag. Co. 68 No 5, 3730 (2020).

24. A.V. Bulashenko, S.I. Piltyay, I.V. Demchenko, J. NanoElectron. Phys. 12 No 6, 06026 (2020).

25. S. Piltyay, A. Bulashenko, O. Sushko, O. Bulashenko, I. Demchenko, Int. J. Model. El. 34 No 5, e2890 (2021).

\title{
Метод математичного синтезу хвилеводних поляризаторів із діафрагмами
}

\author{
А.В. Булашенко ${ }^{1}$, С.І. Пільтяй ${ }^{1}$, I.I. Діхтярук ${ }^{1}$, О.В. Булашенко ${ }^{2}$ \\ ${ }^{1}$ Національний технічний університет України «Київський політехнічний інститут \\ імені Ігоря Сікорського», пр. Перемоги, 37, 03056 Київ, Україна \\ 2 Шосткинський фбаховий коледж імені Івана Кожедуба Сумського державного університету, \\ вул. Інститутська, 1, 41100 Шостка, Україна
}

\begin{abstract}
У статті розроблено новий математичний метод синтезу хвилеводних діадрагмових поляризаторів із оптимальними фазовими характеристиками та узгодженням. Метод використовуе теоретичні одномодові вирази для диференційного фазового зсуву між хвилями з ортогональними лінійними поляризаціями та коефіціента стійної хвилі за напругою для оптимізації геометричних розмірів структури поляризатора. Ці вирази було об’еднано в систему математичних умов для отримання необхідних значень характеристик. Запропонований метод було застосовано для синтезу хвилеводного поляризатора із двома тонкими провідними діафрагмами. Такі діафрагми е еквівалентними індуктивним або емнісним навантаженням у хвилеводній лінії передачі залежно від типу поляризації основної електромагнітної моди. Математичну модель хвилеводного діафрагмового поляризатора було розроблено на основі еквівалентних хвильових матриць. У результаті було визначено основні електромагнітні характеристики за допомогою елементів матриці розсіювання поляризатора. Запропонований аналітичний метод синтезу дозволяе знайти всі оптимальні геометричні розміри діафррагмового поляризатора, включаючи поперечні розміри квадратного хвилеводу, висоти діафрагм і відстані між ними. Варіювання цих розмірів дозволяе отримати необхідні електромагнітні характеристики мікрохвильових хвилеводних пристроїв, а саме: оптимальне узгодження та кросполяризаційну розв'язку в робочій смузі частот. Для поляризатора на основі квадратного хвилеводу з діафрагмами, що був оптимізований для супутникового робочого діапазону частот 8,0-8,5 ГГц, було отримано диференційний фазовий зсув $90^{\circ} \pm 0,5^{\circ}$. Коефіціент стійної хвилі за напругою не перевищуе значення 2 для основних мод вер тикальної та горизонтальної лінійних поляризацій. Кросполяризаційний рівень діафрагмового поляризатора е нижчим за - 34 дБ. Коефіцієнт еліптичності не перевищуе 0,4 дБ. Таким чином, представлений математичний метод одномодового синтезу хвилеводних поляризаторів із діафрагмами може використовуватися для початкової оптимізації перед застосуванням спеціалізованих програм моделювання мікрохвильових пристроїв. Крім цього, запропонований метод математичного синтезу може широко застосовуватися для розроблення нових мікрохвильових поляризаторів, фразозсувачів і фільтрів на основі діафррагм і штирів у хвилеводах.
\end{abstract}

Ключові слова: Електромагнітне моделювання, Мікрохвильова техніка, Хвилеводні компоненти, Синтез мікрохвильових пристроїв, Матриця розсіювання, Матриця передачі, Поляризатор, Хвилеводний поляризатор, Поляризатор із діафрагмами, Колова поляризація. 